\title{
Peran Aparatur Sipil Negara Melalui Pelayanan Prima
}

\author{
JUNAIDI \\ Widyaiswara Badan Pengembangan Sumber Daya Manusia Provinsi Riau \\ JL. Ronggowarsito No 14 Kec. Sail, Pekan Baru Provinsi Riau \\ E-mail : junjoen011@yahoo.co.id
}

\begin{abstract}
Excellent service is an effort to improve the quality of government services to the community as customers and as a reference for the development of service standards. Both servants, customers or stakeholders in service activities, will have a reference on why, when, with whom, where and how services should be done. Excellent service is a translation of the term "Excellent Service" which literally means excellent service and / or best service. It is called very good or best, because it is in accordance with the service standards that are in effect or owned by the agency that provides services. Customer satisfaction is the main goal of excellent service. Therefore, each service apparatus is obliged to strive to satisfy its customers. Customer satisfaction can be achieved if the service apparatus knows who their customers are, both internal customers and external customers. By knowing who the customer is, the servant apparatus will be able to identify what the customer wants.
\end{abstract}

Keywords: Excellent Service, Customer Satisfaction, Service

Sesuai Undang-Undang Republik Indonesia Nomor 5 Tahun 2014 Pasal 10 yang menyebutkan bahwa ada tiga fungsi Aparatur Sipil Negara, antara lain sebagai pelaksana kebijakan publik; pelayan publik; perekat dan pemersatu bangsa.

Dalam menjalankan perannya sebagai pelayanan publik yang diberikan pemerintah kepada masyarakat, sehingga sering dijadikan indikator keberhasilan suatu system penyelenggaraan pemerintahan. Demikian juga dengan program reformasi nasional, tidak akan ada artinya apa-apa manakala pelayanan publik ternyata masih buruk. Apalagi dalam rangka mewujudkan good governance dimana akuntabilitas menjadi salah satu prinsip yang harus dikedepankan dalam penyelenggaraan pemerintahan oleh ASN sebagai pelayanan publik harus mampu memberikan pelayanan yang akuntabel (pelayanan prima) di sektor publik yang tidak bisa ditunda-tunda.

Kepercayaan masyarakat terhadap Pegawai ASN (PNS) yang cenderung negatif (malas, korup, kurang melayani, tidak produktif, dan lain sebagainya) membutuhkan reformasi/perubahan terhadap pola pikir yang berorientasi pada pelayanan masyarakat .Reformasi birokrasi membutuhkan reformasi mendasar yang harus dilakukan terlebih dahulu, yakni reformasi pola pikir (mindset). Pola pikir sendiri terbentuk karena 'imprint' yaitu suatu peristiwa masa lalu yang sangat membekas. Imprint sendiri dapat bersifat positif maupun negatif. Selain itu faktor lingkungan juga sangat mempengaruhi pola pikir penyelenggara pemerintahan, oleh karenanya bagi CPNS/PNS yang sudah terbentuk yang disebabkan karena imprint maupun lingkungan yang bersifat negatif perlu dilakukan perubahan agar dapat menunjukkan perilaku-perilaku positif guna menjalankan pekerjaannya seharihari sesuai dengan konsep diri yang perlu dimiliki seorang PNS.

Oleh karena itu Pegawai ASN harus selalu mengedepankan konsep diri, antara lain (1) bekerja sebagai Ibadah, (2) menghindari sikap tidak terpuji, (3) Bekerja secara profesional, (4) berusaha meningkatkan kompetensi dirinya secara terus menerus, (5) Pelayan dan pengayom masyarakat, (6) Bekerja berdasarkan peraturan yang berlaku (7) tidak rentan terhadap perubahan dan 
terbuka serta bersikap realistis (8) mampu bekerja dalam tim, dan (9) Bekerja secara profesional.

Berkaitan dengan pelayanan, ada dua istilah yang perlu diketahui, yaitu melayani dan pelayanan.Pengertian melayani adalah "membantu menyiapkan (mengurus) apa yang diperlukan seseorang". Sedangkan pengertian pelayanan adalah "usaha melayani kebutuhan orang lain" (Kamus Besar Bahasa Indonesia, 1995). Pelayanan pada dasarnya adalah kegiatan yang ditawarkan oleh organisasi atau perorangan kepada konsumen (yang dilayani), yang bersifat tidak berwujud dan tidak dapat dimiliki. Hal ini sesuai dengan apa yang disampaikan oleh Norman (1991: 14) mengenai karakteristik pelayanan, yakni sebagai berikut:

a. Pelayanan bersifat tidak dapat diraba, pelayanan sangat berlawanan sifatnya dengan barang jadi;

b. Pelayanan itu kenyataannya terdiri dari tindakan nyata dan merupakan pengaruh yang sifatnya adalah tindakan sosial;

c. Produksi dan konsumsi dari pelayanan tidak dapat dipisahkan secara nyata, karena pada umumnya kejadiannya bersamaan dan terjadi di tempat yang sama.

Karakteristik di atas dapat menjadi dasar bagaimana memberikan pelayanan yang terbaik. Pengertian yang lebih luas juga disampaikan oleh Daviddow dan Utal (1989:19) bahwa pelayanan merupakan usaha apa saja yang mempertinggi kepuasan pelanggan (whatever enhances customer satisfaction). Keputusan Menteri Negara Pendayagunaan Aparatur Negara Nomor 63/KEP/M.PAN/7/2003, memberikan pengertian pelayanan publik yaitu segala kegiatan pelayanan yang dilaksanakan oleh penyelenggara pelayanan publik sebagai upaya pemenuhan kebutuhan penerima pelayanan maupun pelaksanaan ketentuan peraturan perundang-undangan.
Standar pelayanan adalah ukuran yang telah ditentukan sebagai suatu pembakuan pelayanan yang baik. Dalam standar pelayanan ini juga terdapat baku mutu pelayanan. Adapun pengertian mutu menurut Goetsch dan Davis (1994), merupakan kondisi dinamis yang berhubungan dengan produk, jasa, manusia, proses dan lingkungan yang memenuhi atau melebihi harapan pihak yang menginginkannya.

Pelayanan prima merupakan terjemahan dari istilah "Excellent Service" yang secara harfiah berarti pelayanan yang sangat baik dan atau pelayanan yang terbaik.Disebut sangat baik atau terbaik, karena sesuai dengan standar pelayanan yang berlaku atau dimiliki oleh instansi yang memberikan pelayanan. Apabila instansi pelayanan belum memiliki standar pelayanan, maka pelayanan disebut sangat baik atau terbaik atau akan menjadi prima, manakala dapat atau mampu memuaskan pihak yang dilayani. Jadi pelayanan prima adalah pelayanan yang mampu memuaskan harapan pelanggan.

Tentunya agar keprimaan suatu pelayanan dapat terukur, bagi instansi pemberi pelayanan yang belum memiliki standar pelayanan, maka terlebih dahulu perlu membuat standar pelayanan prima sesuai dengan tugas dan fungsinya.

Pelayanan merupakan suatu proses. Proses tersebut menghasilkan suatu produk yang berupa pelayanan, kemudian diberikan kepada pelanggan. Sebagai contoh adalah proses pelayanan surat masuk. Proses pelayanan surat masuk adalah sebagai berikut :

a. surat diterima oleh seorang petugas;

b. surat disortir (dipisah-pisahkan);

c. surat diterima pencatat surat dan kemudian dicatat dalam buku agenda atau kartu kendali;

d. surat disampaikan ke pengarah surat;

e. surat di distribusikan ke unit organisasi sesuai dengan alamat yang tertulis dalam surat (sering disebut dengan istilah "unit pengelola"); 
f. Surat diterima oleh unit engolah.

Berdasarkan jenisnya, pelayanan dapat dibedakan menjadi tiga kelompok (Gonroos, 1990), yaitu :

\section{a. core service}

core service adalah pelayanan yang ditawarkan kepada pelanggan, yang merupakan produk utamanya. Misalnya untuk hotel adalah penyediaan kamar dan untuk penerbangan adalah transportasi udara.Suatu lembaga pelayanan mungkin mempunyai beberapa core service, misalnya perusahaan penerbangan menawarkan penerbangan dalam negeri dan luar negeri.

\section{$b$. facilitating service}

facilitating service adalah fasilitas pelayanan tambahan kepada pelanggan, misalnya pelayanan "front office" pada hotel atau pelayanan "check in" pada transportasi udara. Facilitating service ini merupakan pelayanan tambahan tetapi sifatnya wajib.

\section{c. supporting service}

supporting service merupakan pelayanan tambahan (pendukung) untuk meningkatkan nilai pelayanan atau untuk membedakan dengan pelayanan- pelayanan dari pihak "pesaingnya" yang bersifat tidak wajib. Misalnya Restoran pada suatu hotel.Supportingnya adalah welcome drink sebagai pelayanan tambahan yang disediakan untuk meningkatkan daya saing.

Tujuan pelayanan prima adalah memberikan pelayanan yang dapat memenuhi dan memuaskan masyarakat serta memberikan fokus pelayanan kepada masyarakat.Pelayanan prima pada sektor publik didasarkan pada aksioma bahwa "pelayanan adalah pemberdayaan".Pelayanan prima sektor publik tidaklah mencari untung, tetapi memberikan pelayanan sesuai dengan kebutuhan masyarakat secara sangat baik atau terbaik.Dalam hal memberdayakan masyarakat ini, pelayanan yang diberikan tidaklah bertujuan selain mencari untung, juga menjadikan masyarakat justru terbebani atau terberdayakan dengan pelayanan dari pemerintahan yang diterimanya.

Pelayanan prima merupakan suatu upaya peningkatan kualitas pelayanan pemerintah kepada masyarakat sebagai pelanggan dan sebagai acuan untuk pengembangan penyusunan standar pelayanan. Baik pelayan, pelanggan atau stakeholder dalam kegiatan pelayanan, akan memiliki acuan mengenai mengapa, kapan, dengan siapa, dimana dan bagaimana pelayanan mesti dilakukan.

\section{METODE}

Kajian dalam tulisan ini
menggunakan pendekatan kualitatif
deskriptif dimana data yang diperoleh
berasal dari sutudi kepustakaan dan
disajikan secara sistematis untuk
memperoleh gambaran tentang peran ASN
melalui pelayanan Prima, manfaat serta
dampak pelayanan prima bagi ASN
terhadap masyarakat.

HASIL

\section{Prinsip-Prinsip Pelayanan}

\section{Kebijakan Pemerintah}

Di Indonesia, upaya untuk menetapkan standar pelayanan publik dalam kerangka peningkatan kualitas pelayanan publik sebenarnya telah lama dilakukan. Upaya tersebut antara lain ditunjukan dengan terbitnya berbagai kebijakan seperti: a. Inpres No. 5 Tahun 1984 tentang Pedoman Penyederhanaan dan Pengendalian Perijinan di Bidang Usaha; b. Surat Keputusan Menteri Pendayagunaan Aparatur Negara No. 81 Tahun 1993 tentang Pedoman Tatalaksana Pelayanan Umum; c. Inpres No. 1 Tahun 1995 tentang Perbaikan dan Peningkatan Mutu Pelayanan Aparatur Pemerintah Kepada Masyarakat; d. Surat Edaran Menko Wasbangpan No. 56/Wasbangpan/6/98 tentang Langkahlangkah Nyata Memperbaiki Pelayanan 
Masyarakat. Instruksi Mendagri No. 20/1996; e. Surat Edaran Menkowasbangpan No. 56/MK. Wasbangpan/6/98; Surat Menkowasbangpan No.145/MK.Waspan/ 3/1999; hingga Surat Edaran Mendagri No.503/125/ PUOD/1999, yang kesemuanya itu bermuara pada peningkatan kualitas pelayanan; f. Keputusan Menpan No 81/1993 tentang Pedoman Tatalaksana Pelayanan Umum; g. Surat Edaran Depdagri No. 100/757/OTDA tentang Pelaksanaan Kewenangan Wajib dan Standar Pelayanan Minimum, pada tahun 2002; h. Kep. Menpan No: 63/KEP/M.PAN/7/2003 tentang Pedoman Umum Penyelenggaraan Pelayanan Publik; i. Undang-Undang Nomor 25 Tahun 2009 Tentang Pelayanan Publik; j. Peraturan Pemerintah Nomor 96 Tahun 2012 Tentang Pelaksanaan Undang -Undang Nomor 25 Tahun 2009 Tentang Pelayanan Publik; k. Peraturan Menteri Pendayagunaan Aparatur Negara Dan Reformasi Birokrasi Nomor 38 Tahun 2012 Tentang Pedoman Penilaian Kinerja Unit Pelayanan Publik.

Adapun yang dimaksud dengan standar pelayanan (LAN, 2003) adalah suatu tolok ukur yang dipergunakan untuk acuan penilaian kualitas pelayanan sebagai komitmen atau janji dari pihak penyedia pelayanan kepada pelanggan untuk memberikan pelayanan yang berkualitas. Sedangkan yang dimaksud dengan pelayanan berkualitas adalah pelayanan yang cepat, menyenangkan, tidak mengandung kesalahan, serta mengikuti proses dan prosedur yang telah ditetapkan terlebih dahulu. Jadi pelayanan yang berkualitas tidak hanya ditentukan oleh pihak yang melayani, tetapi juga pihak yang ingin dipuaskan ataupun dipenuhi kebutuhannya. Manfaat yang dapat diperoleh dengan adanya standar pelayanan (LAN, 2003) antara lain adalah: a. Memberikan jaminan kepada masyarakat bahwa mereka mendapat pelayanan dalam kualitas yang dapat dipertanggungjawabkan, memberikan fokus pelayanan kepada pelanggan/masyarakat, menjadi alat komunikasi; b. antara pelanggan dengan penyedia pelayanan dalam upaya meningkatkan pelayanan, menjadi alat untuk mengukur kinerja pelayanan serta menjadi alat monitoring dan evaluasi kinerja pelayanan; c. melakukan perbaikan kinerja pelayanan publik. Perbaikan kinerja pelayanan publik mutlak harus dilakukan. Hal ini disebabkan tugas dan fungsi utama pemerintah adalah memberikan dan memfasilitasi berbagai pelayanan publik yang diperlukan oleh masyarakat, mulai dari pelayanan dalam bentuk pengaturan ataupun pelayanan-pelayanan lain dalam rangka memenuhi kebutuhan masyarakat dalam bidang pendidikan, kesehatan, utilitas, sosial dan lainnya; d. Meningkatkan mutu pelayanan. Adanya standar pelayanan dapat membantu unit-unit penyedia jasa pelayanan untuk dapat memberikan pelayanan yang terbaik bagi masyarakat. Dalam standar pelayanan dapat terlihat dengan jelas dasar hukum, persyaratan pelayanan, prosedur pelayanan, waktu pelayanan, biaya serta proses pengaduan, sehingga petugas pelayanan memahami apa yang seharusnya mereka lakukan dalam memberikan pelayanan. Standar pelayanan juga dapat membantu meningkatkan transparansi dan akuntabilitas kinerja suatu unit pelayanan. Dengan demikian, masyarakat dapat terbantu dalam membuat suatu pengaduan ataupun tuntutan apabila tidak mendapatkan pelayanan yang sesuai dengan standar yang telah ditetapkan.

Berdasarkan uraian di atas, maka standar pelayanan menjadi faktor kunci dalam upaya meningkatkan kualitas pelayanan publik. Upaya penyediaan pelayanan yang berkualitas antara lain dapat dilakukan dengan memperhatikan ukuran-ukuran apa saja yang menjadi kriteria kinerja pelayanan. Menurut LAN (2003), kriteria-kriteria pelayanan tersebut antara lain: a. Kesederhanaan, yaitu bahwa tata cara pelayanan dapat diselenggarakan secara mudah, cepat, tidak berbelit-belit, mudah dipahami dan dilaksanakan oleh pelanggan; b. Reliabilitas, meliputi konsistensi kinerja yang tetap menjaga saling ketergantungan antara pelanggan dengan pihak penyedia pelayanan, seperti 
menjaga keakuratan perhitungan keuangan, teliti dalam pencatatan data dan tepat waktu; c. Tanggungjawab petugas pelayanan, yang meliputi pelayanan sesuai dengan urutan waktunya, menghubungi pelanggan secepatnya apabila terjadi sesuatu yang perlu segera diberitahukan; d. Kecakapan petugas pelayanan, yaitu bahwa para petugas pelayanan menguasai keterampilan dan pengetahuan yang dibutuhkan; e. Pendekatan kepada pelanggan dan kemudahan kontak pelanggan dengan petugas, Petugas pelayanan harus mudah dihubungi oleh pelanggan, tidak hanya dengan pertemuan secara langsung, tetapi juga melalui telepon atau internet. Oleh karena itu, lokasi dari fasilitas dan operasi pelayanan juga harus diperhatikan; f. Keramahan, meliputi kesabaran, perhatian dan persahabatan dalam kontak antara petugas pelayanan dan pelanggan; g. Keterbukaan, yaitu bahwa pelanggan bisa mengetahui seluruh informasi yang mereka butuhkan secara mudah dan jelas, meliputi informasi mengenai tata cara, persyaratan, waktu penyelesaian, biaya dan lain-lain; h. Komunikasi antara petugas dan pelanggan, Komunikasi yang baik dengan pelanggan adalah bahwa pelanggan dapat memperoleh informasi yang berhak diperolehnya dari penyedia pelayanan dalam bahasa yang mereka mengerti; i. Kredibilitas, meliputi adanya saling percaya antara pelanggan dan penyedia pelayanan, adanya usaha yang membuat penyedia pelayanan tetap layak dipercayai, adanya kejujuran kepada pelanggan dan kemampuan penyedia pelayanan untuk menjaga pelanggan tetap setia; j. Kejelasan dan kepastian, yaitu mengenai tata cara, rincian biaya layanan dan tata cara pembayarannya, jadwal waktu penyelesaian layanan tersebut. Hal ini sangat penting karena pelanggan tidak boleh ragu-ragu terhadap pelayanan yang diberikan; k. Keamanan, yaitu usaha untuk memberikan rasa aman dan bebas pada pelanggan dari adanya bahaya, resiko dan keragu-raguan. Jaminan keamanan yang perlu kita berikan berupa keamanan fisik, finansial dan kepercayaan pada diri sendiri; 1. Mengerti apa yang diharapkan pelanggan, Hal ini dapat dilakukan dengan berusaha mengerti apa saja yang dibutuhkan pelanggan. Mengerti apa yang diinginkan pelanggan sebenarnya tidaklah sukar. Dapat dimulai dengan mempelajari kebutuhan-kebutuhan khusus yang diinginkan pelanggan dan memberikan perhatian secara personal; $\mathrm{m}$. Kenyataan, meliputi bukti-bukti atau wujud nyata dari pelayanan, berupa fasilitas fisik, adanya petugas yang melayani pelanggan, peralatan yang digunakan dalam memberikan pelayanan, kartu pengenal dan fasilitas penunjang lainnya; n. Efisien, yaitu bahwa persyaratan pelayanan hanya dibatasi pada hal-hal yang berkaitan langsung dengan pencapai sasaran pelayanan dengan tetap memperhatikan keterpaduan antara persyaratan dengan produk pelayanan; o. Ekonomis, yaitu agar pengenaan biaya pelayanan harus ditetapkan secara wajar dengan memperhatikan nilai barang/jasa dan kemampuan pelanggan untuk membayar.

\section{Komitmen Pelayanan}

Pedoman untuk mencapai kesuksesan dalam memberikan pelayanan dengan menggunakan indikator pelayanan seperti diuraikan diatas memerlukan komitmen dari semua komponen/aparatur yang memberikan pelayanan kepada masyarakat. Dukungan dan komitmen yang dimaksudkan disini adalah: a. Kejelasan. Pelayanan yang diberikan kepada masyarakat diperlukan kejelasan terhadap semua hal yang berkaitan dengan sistem dan prosedur pelayanan menurut ketentuan yang berlaku pada organisasi pemerintah (pusat, propinsi, dan kabupaten/kota), sehingga masyarakat (pelanggan) dapat mengerti hak dan kewajibannya untuk mendapatkan pelayanan yang prima dari aparatur birokrasi;

b. Konsistensi. Aparatur birokrasi dalam memberikan pelayanan kepada masyarakat dituntut agar konsisten dalam menerapkan/melaksanakan aturan (pelayanan), sehingga kesan yang selama 
ini berkembang di masyarakat bahwa birokrasi sangat identik dengan "berbelitbelit, biaya mahal dan waktu yang lama" dapat ditepis, sehingga pada gilirannya akan merebut hati masyarakat. Untuk itu, janganlah menunjukkan atau memperkenalkan ketidakkonsistenan antara sistem dan prosedur pelayanan yang berlaku dengan kenyataan dan pandangan masyarakat; c. Komunikasi. Katakan kepada semua masyarakat (pelanggan) bahwa sistem dan prosedur pelayanan yang saya sampaikan merujuk pada peraturan perundangundangan yang berlaku, sehingga masyarakat (pelanggan) tidak perlu berpersepsi/berpretensi negatif pada aparatur birokrasi yang memberikan pelayanan. Perhatikanlah aspek-aspek psikologis yang dialami oleh pelanggan, sehingga tercipta suasana yang harmonis antara pelanggan dan pelayan; d. Komitmen. Bahwa dalam mengimplementasikan pelayanan prima kepada masyarakat diperlukan komitmen yang kuat, mulai dari mengambil keputusan sampai kepada pelaksana keputusan, sehingga pelayanan prima kepada masyarakat dapat dilihat seperti dalam sebuah orkes simphoni. Dalam orkes simphoni semua pemain mempunyai komitmen yang kuat mulai dari tampilan pemainnya sampai pada nada dan iramanya, sehingga hasil yang ditunjukkan dapat menyenangkan semua orang.

\section{Membangun Komitmen Pelayanan Kepada Masyarakat}

Di dalam upaya membangkitkan spirit kepercayaan masyarakat yang menjadi target pelayanan publik, David Osborne memberikan lima prinsip utama untuk membangkitkan kepercayaan masyarakat tersebut, yaitu: Pertama; Masyarakat perlu diyakinkan bahwa birokrasi itu bukanlah suatu gambaran tentang kebobrokan atau hantu (evil); dan masyarakat itu harus merasa yakin bahwa untuk menopang peningkatan "Derajat Civilized" harus memiliki suatu tingkat birokrasi yang bersifat efektif.Pemerintah harus dipandang sebagai suatu mekanisme manajemen yang mampu mewujudkan aspirasi masyarakat yang dilayaninya. Kedua; Masyarakat perlu diyakinkan bahwa untuk meningkatkan kualitas budaya masyarakat secara menyeluruh dibutuhkan kehadiran kualitas pemerintahan yang bersifat efektif, produktif dan efisien. Perlu dipahami bahwa dalam kondisi ekonomi dan sosial yang semakin bersifat "Industrialized" dan pemerintahan dilihat dari aspek fungsi semakin meluas; maka kecenderungan sentralisasi akan semakin besar dan akan mendorong lahirnya standarisasistandarisasi pelayanan baik secara kuantitatif maupun secara kualitatif. Ketiga; Masyarakat perlu diyakinkan bahwa kondisi sumber daya manusia sebagai aparatur pemerintah, bukanlah suatu sentral permasalahan dalam pelayanan publik; tapi sentral permasalahan terletak pada system pelayanan publik yang diterapkan. Masyarakat harus percaya bahwa sebagian besar aparatur pemerintah masih memiliki tanggung jawab yang sangat besar, penuh dedikasi terhadap apa yang menjadi lingkup kerjanya; memiliki keahlian prima; yang biasanya mereka berada pada perangkap system birokrasi yang statis dan sangat menghambat kreativitas mereka. Lebih jauh masyarakat harus memiliki suatu kepercayaan bahwa sistem birokrasi yang statis itu bisa dirubah, dijadikan sistem yang bersifat energik bagi optimasi pelayanan publik. Keempat; Masyarakat harus diyakinkan bahwa pandangan liberalisme, baik yang dimaksud dengan liberalisme tradisional atau liberalisme konservatif dan spirit liberalisme lainnya perlu mendapat tempat lebih besar dalam iklim kinerja pelayanan publik.Pelayanan publik perlu diikuti oleh strategi privatisasi atau swastanisasi; untuk mampu mengimbangi keterbatasan-keterbatasan yang dimiliki oleh pemerintahan dan untuk kepentingan peningkatan kualitas pelayanan.Jadi perlu pertimbangan yang dapat diterima oleh masyarakat secara menyeluruh, privatisasi/ swastanisasi pelayanan publik. Kelima; Masyarakat perlu diyakinkan bahwa, setiap anggota 
masyarakat memiliki peluang yang sama untuk mendapatkan pelayanan publik diberbagai sektor atau bidang pelayanan publik.

\section{Pelayanan Mengacu pada Kepuasan Pelanggan}

Kepuasan didefinisikan sebagai tingkat perasaan seseorang setelah membandingkan kinerja (hasil) yang dirasakan dengan harapannya.Oleh karena itu, maka tingkat kepuasan adalah perbedaan antara kinerja dengan harapan. Dengan demikian apabila dikaitkan dengan pelanggan, maka pelanggan dapat merasakan hal-hal sebagai berikut: a. kinerja di bawah harapan, pelanggan merasa kecewa; $b$. kinerja sesuai harapan, pelanggan merasa puas; c. kinerja melebihi harapan, pelanggan sangat puas.

Bagi aparatur sipil negara, pelayanan perlu mendapat perhatian serius, karena orang yang sangat puas akan mempunyai ikatan emosional dengan suatu produk, dan ini menyebabkan loyalitas orang tersebut menjadi tinggi. Oleh karena itu, aparatur pelayanan dihadapkan pada tantangan membangun budaya organisasi, agar semua orang yang berada di lingkungan organisasi bertujuan memuaskan pelanggan.

Kepuasan pelanggan merupakan tujuan utama pelayanan prima.Oleh karena itu setiap aparatur pelayanan berkewajiban untuk berupaya memuaskan pelanggannya.Kepuasan pelanggan dapat dicapai apabila aparatur pelayanan mengetahui siapa pelanggannya, baik pelanggan internal maupun pelanggan eksternal. Dengan mengetahui siapa pelanggannya, maka aparatur pelayan akan dapat mengidentifikasi apa keinginan pelanggan.

Kepuasan pelanggan dapat dicapai apabila keinginan atau harapan pelanggan dapat terpenuhi. Mengenai mutu, Tjiptono (1997) menyatakan bahwa sedikitnya ada tiga level (tingkat) harapan pelanggan, yaitu: a. Harapan pelanggan yang paling sederhana dan berbentuk asumsi "must have" atau "take it for granted". Misalnya 1) saya berharap perusahaan penerbangan menerbangkan saya sampai tujuan dengan selamat, atau 2) saya berharap bank dapat menyimpan uang saya dengan aman dan menangani saldo rekening saya dengan benar; b. Pada level kedua, kepuasan pelanggan dicerminkan dalam pemenuhan persyaratan dan atau spesifikasi tertentu. Misalnya 1) saya berharap dilayani dengan ramah oleh pegawai perusahaan penerbangan, atau 2) saya pergi ke bank dan tellernya ternyata sangat ramah, informatif dan suka menolong transaksitransaksi saya; c. Pada level ketiga ini pelanggan menuntut suatu kesenangan (delightfulness) atau jasa yang demikian bagusnya, sehingga membuat pelanggan tertarik. Misalnya 1) perusahaan penerbangan itu member semua penumpang makanan yang sama dengan yang diberikan khusus kepada penumpang kelas satu oleh perusahaan penerbangan yang lainnya. Contoh lain adalah 2) semua karyawan melayani saya dengan penuh respek dan menjelaskan sesuatunya secara cermat. Akan tetapi yang paling mengesankan saya adalah ketika mereka menelepon saya dirumah hari berikutnya dan menanyakan apakah saya baik-baik saja; d. Dimensi Pelayanan Prima Gaspersz (1997) menyatakan bahwa ada beberapa dimensi yang harus diperhatikan untuk meningkatkan mutu pelayanan yaitu: 1) Ketepatan waktu pelayanan. Hal-hal yang perlu diperhatikan disini terkait dengan waktu tunggu dan waktu proses; 2) Akurasi pelayanan. Berkaitan dengan reliabilitas pelayanan dan bebas dari kesalahan pelayanan; 3) Kesopanan dan keramahan dalam memberikan pelayanan. Terutama bagi mereka yang berinteraksi dengan pelanggan eksternal seperti operator telepon, petugas keamanan (SATPAM), pengemudi, staf administrasi, kasir, petugas penerima tamu, perawat dan lain-lain; 4) Tanggung jawab. Berkaitan dengan penerimaan pesanan dan penanganan keluhan dari pelanggan eksternal; 5) Kelengkapan. Berkaitan dengan lingkup 
pelayanan dan ketersediaan sarana pendukung; 6) Kemudahan mendapatkan pelayanan. Berkaitan dengan banyaknya "outlet" banyaknya petugas yang melayani, seperti kasir, staf administrasi dan lainnya. Banyaknya fasilitas pendukung, seperti komputer untuk memproses data dan lain-lain; 7) Variasi model pelayanan. Berkaitan dengan "inovasi" untuk memberikan pola-pola baru dalam pelayanan; 8) Pelayanan Pribadi. Berkaitan dengan fleksibilitas, penangananan permintaan-permintaan khusus, dan lain-lain. 9) Kenyamanan dalam memperoleh pelayanan. Berkaitan dengan lokasi, ruang dan tempat pelayanan, kemudahan menjangkau, tempat parker kendaraan, ketersediaan informasi, petunjukpetunjuk dan lain-lain; 10) Atribut pendukung pelayanan lainnya. Seperti lingkungan, kebersihan ruang tunggu, fasilitas musik, AC dan lainlain.

\section{Mendahulukan Kepentingan Pelanggan}

Pelayanan Prima adalah pelayanan yang memuaskan pelanggan.Salah satu indikator adanya kepuasan pelanggan adalah tidak adanya keluhan dari pelanggan. Akan tetapi, didalam praktek, keluhan-keluhan pelanggan ini akan selalu ada. Organisasi pemberi pelayanan wajib menanggapi dan menghadapi keluhan pelanggan tersebut untuk kepentingan dan kepuasan pelanggan.Untuk itu, pemberi pelayanan perlu mengetahui sumbersumber keluhan pelanggan dan mengetahui cara-cara mengatasi keluhan pelanggan.

Menurut Endar Sugiarto (1999), sumber-sumber keluhan pelanggan antara lain adalah: pelanggan internal dan pelanggan eksternal. Pelanggan internal adalah pegawai instansi/organisasi yang bersangkutan dan para pemimpin instansi/organisasi yang bersangkutan. Seorang pegawai suatu instansi/organisasi yang tidak betah bekerja karena lingkungan kerja dan situasi pegawai yang ada di dalamnya. Suasana nyaman dan harmonis akan mempengaruhi kesiapannya dalam menghadapi pelanggan eksternal. Para pemimpin instansi/organisasi dapat menjadi sumber keluhan, karena pemimpin sering mendapat masukan dari para pelanggan eksternal tentang pelayanan di instansinya.Perhatian utama suatu instansi/organiasi adalah pelanggan eksternal, yaitu masyarakat. Kunci utama keberhasilan pelayanan terletak pada cara instansi/organisasi tersebut memperlakukan pelanggan eksternal ini.

Menurut Endar Sugiarto (1999), keluhan pelanggan dapat dikategorikan/ dikelompokkan menjadi empat, yaitu: 1) Mechanical Complaint (Keluhan Mekanikal). Mechanical complaint adalah suatu keluhan yang disampaikan oleh pelanggan sehubungan dengan tidak berfungsinya peralatan yang dibeli/disampaikan kepada pelanggan tersebut; 2) Attitudinal Complaint (Keluhan akibat sikap petugas pelayanan). Attitudinal complaint adalah keluhan pelanggan yang timbul karena sikap negatif petugas pelayanan pada saat melayani pelanggan. Hal ini dapat dirasakan oleh pelanggan melalui sikap tidak peduli dari petugas pelayanan terhadap pelanggan; 3) Service Related Complaint (Keluhan yang berhubungan dengan pelayanan).

Service related complaint adalah suatu keluhan pelanggan karena hal- hal yang berhubungan dengan pelayanan itu sendiri. Misalnya seseorang mendaftar untuk ikut suatu Diklat, ternyata formulir pendaftaran belum siap dan oleh petugas diminta untuk menunggu;

\section{Unusual Complaint (Keluhan yang aneh) \\ Unusual complaint adalah keluhan} pelanggan yang bagi petugas merupakan keanehan (tidak wajar/tidak umum).pelanggan yang mengeluh seperti ini sebenarnya secara psikologis adalah orang-orang yang hidupnya tidak bahagia atau kesepian. Ada beberapa hal yang perlu diperhatikan dalam menghadapi keluhan pelanggan, antara lain adalah: 1) Pelanggan biasanya marah pada saat menyampaikan keluhan. Oleh karena itu, petugas pelayanan tidak boleh terpancing untuk ikut marah; 2) 
Petugas pelayanan tidak boleh memberikan janji-janji yang sebenarnya sulit dipenuhi serta tidak menjanjikan sesuatu yang berada di luar wewenangnya; 3) Jika permasalahan tidak dapat diselesaikan sedangkan petugas sudah berbuat maksimal, petugas harus berani menyatakan menyerah dengan jujur; 4) Ada pelanggan yang selalu mengeluh. Untuk menghadapi pelanggan seperti itu, petugas harus sabar dan melakukan pendekatan secara khusus.

Pelayanan dengan Sepenuh Hati

Menurut Endar Sugiarto (1999), pada hakekatnya pelanggan itu tidak membeli produk, tetapi mereka membeli pelayanan. Ini merupakan falsafah bisnis dalam upaya memberikan pelayanan yang prima.Pelayanan disini adalah pelayanan dalam segala bentuk kreasi dan manifestasinya. Untuk itu, kita lebih banyak belajar tentang para pelanggan kita, agar kita dapat memberikan pelayanan dengan sepenuh hati dan dengan cara yang lebih baik di masa yang akan datang.

\section{Budaya Pelayanan Prima}

Menganggap bahwa pelayanan prima sebagai suatu budaya berarti melakukan kegiatan pelayanan sebagai suatu hal yang membanggakan dengan nilai luhur yang di junjung tinggi.Budaya pelayanan prima adalah sebuah budaya yang kuat yang mewarnai sifat hubungan antara instansi/organisasi pemberi pelayanan dengan pelanggannya dan dapat menjadi sarana yang sangat baik untuk memperoleh perhatian pelanggan dari instansi/organisasi pemberi pelayanan.Budaya pelayanan prima dibentuk oleh sikap karyawan dan manajemen instansi/organisasi pemberi pelayanan.

\section{Sikap Pelayanan Prima}

Sikap pelayanan prima berarti pengabdian yang tulus terhadap bidang kerja dan yang paling utama adalah kebanggaan atas pekerjaan.Sikap anda dapat menggambarkan instansi/organisasi anda.Anda adalah perwakilan instansi/organisasi baik secara langsung maupun tidak langsung. Pelanggan akan menilai instansi/organisasi dari kesan pertama mereka dalam berinteraksi dengan orang-orang yang terlibat dalam instansi/organisasi tersebut. Apabila pagi itu kebetulan andalah orang pertama yang berhubungan dengan pelanggan, anda akan mewakili gambaran dari instansi/organisasi anda.

Sentuhan Pribadi Pelayanan Prima

Pelayanan prima sangat memperhatikan individu sebagai pribadi yang unik dan menarik.Setiap pelanggan memiliki sifat dan dapat membuat para petugas bahagia atau kecewa. Sentuhan pribadi mengarahkan para petugas pelayanan untuk berpikir bahwa memperlakukan orang lain sebagaimana kita memperlakukan diri kita sendiri perlu selalu dipraktekan. Yang diutamakan dalam pelayanan prima bukanlah slogan-slogan untuk memberikan pelayanan terbaik bagi pelanggan, melainkan bentuk nyata pelayanan yang sebelumnya sudah diberikan dalam pelatihanpelatihan dan dapat diterapkan pada saat praktek di lapangan, ketika berhubungan langsung dengan pelanggan. Karena pelayanan prima merupakan budaya, identitas, sarana kompetisi, pelanggan merasa penting, rekan sekerja merasa nyaman bersama kita dan kita dapat melayani pelanggan dengan cepat, tepat, ramah, mengutamakan kepuasan pelanggan, menepati janji, bahasa yang baik dalam bertelepon, menunjukkan etika dan sopan santun, merasa puas dan bangga akan pekerjaan kita, bekerja dengan antusias, kepercayaan diri yang tinggi, menawarkan bantuan, senyum yang tulus, humor yang menyenangkan, mendengarkan dengan baik dan dengan konsep win-win.

Pelayanan prima sesuai dengan Pribadi Prima

Konsep pribadi prima meliputi unsur-unsur kepribadian, penampilan, perilaku dan komunikasi yang prima. Seseorang dapat dikatakan memiliki pribadi 
prima apabila: tampil ramah; tampil sopan dan penuh hormat; tampil yakin; tampil rapi; tampil ceria; senang memaafkan; senang bergaul; senang belajar dari orang lain; senang pada kewajaran; senang menyenangkan orang lain.

\section{PEMBAHASAN}

\section{Memahami Pelanggan}

Customer (pelanggan) yang dimaksudkan di dalam modul ini adalah siapa saja yang berkepentingan dengan produk layanan kita.Karena itu, customer dapat berupa individu (perorangan), kolektif (organisasi), maupun masyarakat dalam arti luas. Dengan demikian, customer (pelanggan) dapat dikategorikan dalam dua jenis, yaitu: 1. Pelanggan internal (internal customer) adalah pelanggan yang berasal dari dalam organisasi (instansi) itu sendiri. Pelanggan internal dapat dibagi kedalam dua bagian, yaitu a) pelanggan internal organisasi dan b) pelanggan internal pemerintah. Pelanggan internal dapat dilihat dari dalam lingkungan organisasi, sehingga meskipun bagian/unit kerja kita berbeda, namun masih dalam lingkungan organisasi, maka pelanggan tersebut dapat dikategorikan sebagai pelanggan internal; 2. Sedangkan pelanggan internal pemerintah adalah pelanggan yang walaupun instansi kita berbeda, namun instansi pelanggan itu adalah instansi pemerintah, pelanggan tersebut dapat dikategorikan sebagai pelanggan internal pemerintah (pelanggan internal dalam skala makro).

Pelanggan adalah siapa saja yang terkena dampak dari produk atau proses pelayanan. Pelanggan dapat dibedakan menjadi dua, yaitu pelanggan internal dan pelanggan eksternal.Pelanggan internal adalah mereka yang terkena dampak dari produk dan merupakan anggota organisasi yang menghasilkan produk tersebut.Sedangkan pelanggan eksternal adalah mereka yang terkena dampak dari produk, tetapi bukan anggota organisasi penghasil produk (pelanggan eksternal adalah masyarakat).

Untuk dapat meningkatkan citra positif dimata pelanggan, perlu diperhatikan halhal sebagai berikut :

\section{Membangun citra diri}

Cara-cara untuk membangun citra diri positif di mata pelanggan adalah antara lain : a. memperhatikan pentingnya kesan awal; b. pendekatan awal dapat mempengaruhi hubungan selanjutnya. Hindari kesalahan kecil apapun, karena akan membutuhkan banyak waktu untuk memperbaiki kesalahan tersebut; c. Jangan membuat orang lain menunggu, karena ia bisa frustasi; d. Sapalah pelanggan dengan menyebut namanya; e. Usahakan selalu bersikap ramah, sampaikan salam sesuai waktu, misalnya selamat pagi, ada yang bisa saya Bantu?; f. Pada waktu berbicara, pandang matanya; g. Tersenyum setiap saat. Dengan tersenyum hati anda menjadi gembira; h. Kegembiraan dapat menampilkan wajah berseri; i. Berbicara dengan jelas, dengan kata-kata yang dipahami pelanggan; j. Hindari beban pikiran yang menyebabkan perhatian pelanggan terpecah.

\section{Berusaha mengerti terlebih dahulu, baru dimengerti}

Apabila seorang pelanggan datang untuk memperoleh bantuan anda, anda hendaknya tidak bersikap serba tahu atau seolah-olah sudah mengerti terlebih dahulu apa yang diinginkan pelanggan. Dekati pelanggan dan bersiaplah untuk mendengarkannya. Jangan disibukkan oleh kegiatan lain, sehingga terkesan perhatian anda terbagi.

\section{Mengenal karakter pelanggan}

Keterampilan dasar pelayanan. Ada keterampilan dasar yang dapat diterapkan dalam semua strategi pelayanan, yaitu: 1) Pusatkan perhatian pada pelanggan. Cara yang dapat ditempuh: a) Mendengarkan dengan penuh perhatian dan jangan sekali-kali memotong pembicaraan; b) Perhatikan sikap tubuh anda, bertindak secara tenang dan rileks; c) Menatap mata pelanggan anda pada saat 
berbicara dan tersenyum; d) Perhatikan ekspresi wajah anda, dan selalu tampilkan senyum anda; e) Menanggapi pembicaraan pelanggan apabila pelanggan mengharapkan tanggapan anda; f) Perhatikan nada bicara anda, jangan terlalu rendah (kurang percaya diri) atau terlalu tinggi (kesal, marah dan emosi); g) Menempatkan kepentingan pelanggan pada nomor satu dan orang lain, seperti rekan sekerja dan atasan pada prioritas berikutnya, apabila sedang melayani pelanggan. 2) Memberikan pelayanan yang efisien. Cara yang dapat dilakukan: a) melayani pelanggan berikutnya segera setelah selesai dengan pelanggan pertama; b) pergunakan waktu seakurat mungkin; c) berbicara seperlunya kepada pelanggan; d) merencanakan apa yang selanjutnya akan dilakukan; e) menindaklanjuti pelayanan sampai tuntas; f) menjawab pertanyaan secara singkat, tepat, cepat dan tidak berteletele. 3) Meningkatkan perasaan harga diri pelanggan. Cara yang dapat dilakukan: a) mengenali kehadiran pelanggan dengan segera; b) selalu menggunakan nama pelanggan sesering mungkin; c) tidak menggurui pelanggan, bagaimanapun pintarnya anda; d) memuji dengan tulus dan memberikan penghargaan kepada pelanggan; e) memperlakukan pelanggan sebagai orang dewasa. 4) Membina hubungan baik dengan pelanggan. Cara yang dilakukan: a) mendengarkan apa yang disampaikan oleh pelanggan tanpa memotong pembicarannya; b) menunjukkan simpati dan berbicara dengan penuh perasaan, untuk menunjukkan bahwa anda mengerti dan memahami perasaan pelanggan; c) mempersilahkan pelanggan menanggapi dan berusaha menyelesaikan masalahnya. 5) Dapat menentukan apa keinginan pelanggan. Cara yang dilakukan: a) menanyakan kepada pelanggan; b) mengulangi kembali apa keinginan pelanggan, kemudian menarik inti dari apa yang dikatakannya. 6) Mengalihkan pelayanan ke orang lain. Cara yang dilakukan: a) bila seorang pelanggan meminta pelayanan di luar kemampuan anda, cara terbaik adalah mengalihkan pelayanan tersebut kepada orang lain yang lebih mampu. Dengan pengalihan tersebut akan terlihat bahwa organisasi anda telah bekerja dengan profesisonal; b) setelah mengetahui keinginan pelanggan, anda menjelaskan kepadanya sambil meminta maaf bahwa anda tidak mampu melayaninya, karena orang lain akan lebih baik melayaninya; c) hal ini juga harus dijelaskan dihadapan orang yang hendak menggantikan anda. Perkenalkan orang tersebut kepada pelanggan.

\section{Cara meningkatkan citra poisitif dimata pelanggan.}

Cara untuk meningkatkan citra positif dimata pelanggan adalah dengan mengenal karakter pelanggan dan cara menghadapinya. a. Pelanggan yang pendiam: 1) Beberapa faktor yang menyebabkan seorang pelanggan pendiam; a) Adanya rasa malu pada diri pelanggan, sehingga ia tidak memiliki keberanian untuk menyatakan pendapatnya dengan jelas; b) Pelanggan tidak mau atau segan berbicara karena sedang memikirkan sesuatu; c) Berdasarkan perkiraan, pelanggan yang pendiam memiliki kelainan psikis. 2) Cara menghadapi pelanggan yang pendiam, antara lain sebagai berikut: a) Pelanggan yang pendiam dan cenderung pemalu akan merasa tentram jika dihadapi dengan ramah tamah dan penuh perhatian; b) Jika pelanggan seolah-olah sedang memikirkan sesuatu, sebaiknya petugas jangan mengajak berbicara tetapi cukup melontarkan pertanyaan-pertanyaan yang dapat menarik perhatian pada produkproduk yang ditawarkan; c) Jika menemui pelanggan yang kesulitan dalam bicara (gagap) petugas hendaknya jangan terpaku pada keadaan tersebut dan hendaknya bersikap biasa saja. b. Pelanggan yang tidak sabar: tips menghadapinya: 1) Mengenali pelanggan yang tidak sabar melalui sikapnya, lalu meminta maaf kepadanya atas tertundanya pelayanan; 2) Mengatakan kepadanya bahwa dia akan 
dibantu semaksimal mungkin dan sesegera mungkin; 3) Secara cepat dan efisien menangani situasi tersebut dan bila perlu menenangkan pelanggan tersebut; 4) Mengucapkan terima kasih bahwa pelanggan tersebut masih bersedia menunggu; 5) Mengucapkan terima kasih sekali lagi kepada pelanggan tersebut dan meminta maaf sekali lagi atas ketidak nyamanan dalam pelayanan. c. Pelanggan yang tidak banyak bicara: tips menghadapinya: 1) Mengenali kedatangan pelanggan dengan mengucapkan salam; 2) Menawarkan bantuan yang diperlukan pelanggan tersebut; 3) Bila pelanggan masih terus berbicara petugas mengalihkan perhatiannya pada hal-hal yang ditawarkan dengan penjelasan yang cukup; 4) Menawarkan bantuan dan memuji kehebatannya berbicara; 5) Bila perlu bergabung dalam pembicaraan tersebut sambil sekali-sekali memberikan pujian; 6) Meminta alamat dan nomor teleponnya. 7) Pelanggan jenis ini senang sekali jika mendapat perhatian. d. Pelanggan yang senang mendebat/berdebat, tips menghadapinya: 1) Tidak menunjukkan reaksi apabila pelanggan tersebut berada pada pihak yang salah, sebab jika menunjukkan reaksi, akan timbul diskusi yang berkepanjangan; 2) Bersikap tenang, tidak gugup dan tidak terpancing untuk marah; 3) Membatasi percakapan pada masalah yang sedang dihadapi, tidak menyimpang dari pokok pembicaraan; 4) Mengemukakan argumen yang masuk akal, agar pelanggan menghargai anda. Apabila pelanggan sudah tenang, anda mulai memberikan pelayanan; 5) Mengulangi argumen anda sekedar untuk mengingatkannya apabila pelanggan kembali bersikeras dengan pendapatnya; 6) Mencari kelemahan dari argumen pelanggan dan menunjukkan kekeliruannya agar pelanggan tenang; 7) Apabila anda dapat menguasai keadaan, pelanggan akan lunak. e. Pelanggan yang memiliki banyak permintaan: tips menghadapinya: 1) Mengucapkan salam bila ia datang kepada anda. Bila melalui telepon, anda harus menggunakan cara bertelepon yang baik; 2)
Mendengarkan permintaannya; jika memungkinkan membuat ringkasan atas permintaan tersebut. Permintaan tersebut bisa di penuhi bisa tidak, tergantung kebijaksanaan perusahaan; 3) Sesegera memenuhi permintaan pelanggan, jika memungkinkan, dan tidak melakukan kesalahan dalam melayani, karena ia akan terus mencecar anda jika ada kesalahan sedikit saja; 4) Meminta maaf dan menyarankan alternatif lain jika pelanggan merasa tidak puas atas pelayanan yang diberikan; 5) Segera memberitahu supervisor sambil menyebutkan permintaan pelanggan jika anda tidak mampu melayani pelanggan tersebut; 6) tersenyum setiap saat, meskipun merasa jengkel.

\section{SIMPULAN}

Dalam rangka memberikan pelayanan kepada masyarakat, perlu dukungan dan komitmen, antara lain adanya kejelasan pelayanan yang diberikan dan konsistensi ASN dalam memberikan pelayanan terbaik, mengkomunikasikan peraturan perundang-undangan yang berkaitan dengan pelayanan.

Pelanggan adalah siapa saja yang terkena dampak dari produk atau proses pelayanan. Pelanggan dibedakan menjadi dua yaitu pelanggan internal dan pelanggan eksternal. Pelanggan adalah siapa saja yang berkepentingan dengan produk layanan kita, oleh karena itu pelanggan dapat berupa individu, kolektif maupun masyarakat dalam arti luas.

Dalam rangka menghadapai persaingan global, maka kepuasan pelanggan merupakan salah satu senjata untuk menarik investor untuk menanamkan modalnya di Indonesia. Oleh karena itu pelayan prima merupakan solusi yang tepat bagi setiap ASN dalam mewujudkan kepuasan pelanggan yang dimaksud.

"Penulis mengucapkan terimakasih kepada Jurnal Karya Aparatur BPSD Peovinsi Riau yang telah bersedia menerbitkan karya tulis ini. semoga apa yang telah kami tulis dapat bermanfaat bagi setiap pembaca dan mohon 
maaf jika terdapat kesalahan. Saran dan keritik sangat kami harapkan demi perbaikan tulisan ini".

\section{DAFTAR RUJUKAN}

Avis, Warren, 1986, Take A Chance To Be First (Eds.,) Indonesia Meraih Peluang Menjadi Yang Pertama. Mutiara Utama Indonesia.

Bell, Chip R., 1996, Customers as Partners (Eds.,) Indonesia 1997, Pelanggan Sebagai Mitra Usaha Menjalin Hubungan Yang Abadi, Profesional Books, Indonesia.

David Farnham dan Sylvia Horton, 1993, Managing the New Public Services, Macmillan, London

David Osborne dan Peter Plastrik, 1996, Banishing Bureaucracy-The Five Strategies for Reinventing Government, Addison-Wesley Publishing Company;

David Osborne dan Ted Gebler, 1992, Reinventing Government-How the Enterpreneural Spirit is ransforming the Public Sector, Addison Wesley Publishing Inc.

Devry, 1994, Good Service Is Good Business, Practice Hall, Australia.

Donna Williams, Merubah Pola Pikir, artikel, http://www.donnawilliams.net, 2008

Gaspersz, Vincent (Eds.,) Indonesia, Manajemen Kualitas;Penerapan Konsep- konsep Kualitas Dalam Manajemen Bisnis Total, Gramedia, Indonesia.

Fisip-UI, 1994, Jurnal Ilmu Administrasi dan Organisasi, Nomor 3, Jakarta;
Foster, Timothy R. V, 1997, 101 Ways to Boost Customer Satisfaction, Kogan.

Hopson, Barrie \& Scally Mike, 1991, 12 Steps to Success Through Service, Lifeskills Communications Ltd.

James, Jennifer, 1996, Thinking in The Future Tense, Jennifer James Inc.

Lawrence E Shapiro, Emosional Intelligence, PT Gramedia, Pustaka Utama, Jakarta, 1997

Lukman, Sampara, 1999, Manajemen Kualitas Pelayanan, STIALAN Press, Jakarta.

Macaulay, Steve \& Cook Sarah, 1993, How to Improve Your Customer Service (Eds.,) Indonesia, 1997, Kiat Meningkatkan Pelayanan bagi Pelanggan, Gramedia, Jakarta.

Morgan, Rebecca L, 1996, Calming Upset Customers, Crip Publication, Inc.

Patricia W. Ingraham, Barbara S. Romzek \& Associates, 1994, New paradigm for Government-Issues for the Changing Public Service, Jossey Bass Publisher, San Francisco

Senge, P. (1990). The Fifth Discipline. New york: Doubleday/ Currency.

Sugiarto, Endar, 1999, Psikologi Pelayanan dalam Industri Jasa, Gramedia, Jakarta.

Taufik Bahudin, Braintware Management, Generasi Ke lima Manaement SDM, Elek Media Komputindo, Jakarta, Desember 2003

Walker, Dennis, 1996, Customer First (Eds.,), Indonesia, 1997, Mendahulukan Pelanggan, 
Strategi untuk Memberikan

Pelayanan Bermutu.

Wellington, Patricia, 1998, Kaizen,

Strategies for Customer Care (Eds.,)

Indonesia, 1998, Strategi Kaizen untuk Kepedulian pada Pelanggan, Batam Center, Indonesia.

William James, Father of America psychology, artikel 10 Agustus 2008

Yeheskel Hasenfeld, 1983, Human Service Organizations, Printice- Hall Inc, New Jersey. 